Article

\title{
The Relationship between Innovation and Sustainability: A Bibliometric Review of the Literature
}

\author{
Dorin Maier*, Andreea Maier, Ioan Așchilean, Livia Anastasiu $@$ and Ovidiu Gavriș \\ Department of Buildings and Management, Technical University of Cluj-Napoca, 400020 Cluj-Napoca, Romania; \\ andreea.maier@ccm.utcluj.ro (A.M.); ioan.aschilean@ccm.utcluj.ro (I.A.); livia.anastasiu@ccm.utcluj.ro (L.A.); \\ ovidiu.gavris@ccm.utcluj.ro (O.G.) \\ * Correspondence: dorin.maier@ccm.utcluj.ro
}

Received: 6 April 2020; Accepted: 15 May 2020; Published: 16 May 2020

\begin{abstract}
The research conducted in this paper is directed towards a bibliometric review and a visualization analysis of the relationship between innovation and sustainability. The main objective is to empirically document the intellectual structure, the volume and the knowledge-development directions. For this objective, we used the VOS Viewer software and the scientific databases ISI Web of Science (WoS). We identify that there is a big increase in volume of articles on innovation and sustainability published in the last 10 years, from 2010 up to 2019, compared to the entire period before 2010. Given the large amount of the literature, we form an ample database of 436 peer-reviewed articles published in the last 10 years. The bibliometric analysis reveals the most influential journals, authors and papers in the studied field. This research reveals that by combining the main aspects of innovation and sustainability in a single concept like "sustainable innovation", an emerging topic can appear, and it can offer new research directions in the very big field of innovation and in the new and actual field of sustainability.
\end{abstract}

Keywords: innovation; sustainability; sustainable innovation; business innovation; sustainable development; sustainability-oriented innovation; eco innovation

\section{Introduction}

In the current socio-economic context, businesses are facing serious challenges and they are forced to find better and new methods to stay competitive, to increase their profit, and overall, to increase their performance. Innovation has always been critical for long-term business success. Throughout history, organizations which have innovated successfully have typically been rewarded with growth, profits and access to new markets [1]. Constant innovation has become a critical factor for achieving competitive advantages [2]. Innovation has been widely acknowledged as a key mechanism for addressing sustainable development concerns $[3,4]$.

Many organizations were accustomed to plans and actions that enforced their race toward competitiveness and ignored crucial environmental issues [5]. Thus, in the last few decades there has been a big interest among scientists, practitioners, and even the public, toward conserving the environment along with using resources efficiently (ecological concerns), improving the standard of human living (social challenges), and advancing long-term economic competitiveness (economic matters) [6].

Starting with the publication of the Brundtland Report (United Nations, 1987) [7], a productive discussion on the relationship between sustainability, transformation and innovation began. This debate covers different levels of action and research, from environmental innovation and societal transitions [8] 
or socio-technical transitions, to sustainability in multiple systems [9], and to how firms generate new capabilities for sustainable business model innovation [3,10] and green product innovation [11].

The literature expounds the idea that innovation can be driven by sustainability [12]. Moreover, the role of innovation in the quest for sustainability has received considerable attention from academics and businesses [13]. It has been argued that firms have no choice but to make sustainability-oriented 'changes' to the status quo of the value chain, product/service offerings and business model in order to remain competitive [14]. The increased interest of the policy-makers, practitioners and researchers in the sustainability and sustainable development issues also generates approaches related to the important connection between innovations and sustainability [3,15-17].

\section{Research Purpose}

The main purpose of this research is to identify common points and future interdisciplinary topics between innovation and sustainability. For this purpose, we use bibliometric methods that allow us to empirically document the volume, the intellectual structure, and the knowledge-development directions, in the field. Using a combination of bibliometric, text-mining and visualization analyses, we address the following research questions:

1. What is the volume of published articles with the innovation and sustainability topic?

2. What are the most influential journals, authors and research papers in the field?

3. What is the intellectual structure in the studied field?

4. Which are the most addressed research topics in the domain?

Considering the purpose of this paper and the existence of the two main research directions, innovation and sustainability, the first step of the research was to form a sample database from published papers on the two topics. The sample database was formed by interrogating the ISI Web of Science database as the main database, but we tried to also identify some important papers from Scopus database. The extraction of data for the bibliometric review was done using Preferred Reporting Items for Systematic Reviews and Meta-Analyses (PRISMA) method, and thus we established a sample of 436 peer-reviewed journal articles.

The research method used to answer the research questions is a bibliometric review of the literature $[18,19]$. The literature states that the value of bibliometric methods is given by its ability to analyze the evolution of scientific literature over time, and reveal the intellectual relationships of the knowledge in the field. Given the purpose of this paper, we needed to choose a research methodology that can manage the entire diversity of the knowledge [20]. The analysis of the literature was done from a descriptive point of view, and in this way, it can offer information for the new researchers about the most frequently cited authors and papers in the field. Besides this information, by performing a keyword co-occurrence analysis, we could obtain supplementary data regarding the topics that are the most studied, and how these topics evolve in popularity over the years. By having this data, the researchers can have a good reference base and can also identify the points where further studies are needed.

The paper is structured to offer first a short review of the main definitions of the two concepts, innovation and sustainability, and also some combined approaches, like the sustainable innovation. In the next section of the paper we present the methodology used in this research, showing the data collection extraction and analysis. The next part of the paper is reserved for presenting the research results. We close the paper with the sections of discussions and conclusions, where we highlight the main interpretation and implication of the results, and also we present the limitations and future research directions.

\section{Short Conceptual Background of the Review}

Given the purpose of this study, in this section we want to highlight the basic notions related to the innovation and sustainability concepts, and also their connections. Any manufacturing system, beside 
business requirements, has some social and environmental responsibilities. In order to respond to these responsibilities, the importance of sustainable products and innovation must increase. In the literature, we can find different terminologies and definitions for sustainability and innovation, and even for a combination of the two concepts as sustainable innovation. The links between the two concepts are also related in the literature as "sustainability-oriented innovation", or "sustainability-related innovation".

Innovation is not only the organization's path to success in the business environment, but also an essential condition for maintaining it in a highly competitive market [21]. In the last two decades, innovation has become an attractive field of study for researchers, who have tried to define, classify and investigate its impact on the performance of organizations, in particular because of its practical relevance.

Being a highly studied concept, innovation is defined in many ways by different researchers. For this study we will use the definition provided by the Organization for Economic Cooperation and Development (OECD). In the latest version of the Oslo Manual 2018 [22] innovation is defined as "a new or improved product or process (or combination thereof) that differs significantly from the unit's previous products or processes and that has been made available to potential users (product) or brought into use by the unit (process)". We can observe that the general definition of innovation, given by OECD, is addressed to any organization, as it uses the generic term of "unit" for those responsible of innovation. This definition can be addressed only to the business sector, and thus we can speak about business innovation, where the company becomes the main entity responsible for innovation.

The concept of sustainability is debated in the environmental protection issues since the Brundtland Commission, in 1987, defined sustainable development as: "Development that meets the needs of current generations without compromising the ability of future generations to meet their needs and aspirations" [7]. Since then, the development of the concepts had a big degree of ambiguity, and the researchers have tried to understand the concept as much as possible; thus we find in the literature a lot of definitions for sustainability $[23,24]$. The initial rise of the sustainability concept was a response to the global ecological crises, mainly due to the intense industrial exploitation of natural resources and the continued degradation of the environment. As such, its initial purpose was to protect and preserve the quality of the environment. From that initial role, the concept expanded its influence, to the entire quality of life from an economic and social point of view. In this sense, sustainability activities can be seen as a catalyst for changing and aligning the cleaner production requirements with the business's and society's expectations [12].

In the vision of sustainable development, the progress integrates inseparable short- and long-term goals, economic and environmental issues, or local and global action. The principle of sustainable development implies the search for a stable theoretical framework that can help to manage any situation where humans and the environment are found. Any changes in the current state require answers to a series of questions on how to achieve the transition to the new paradigm. Even if we all agree that the world and global society need to be aware and become more responsible with environmental and also social and economic capital, we need to be aware of the fact that this can be done only by creating new ideas and innovations.

Combining the concept of sustainability with the concept of innovation seems a good way to approach the new paradigm. By this combination, several concepts appear, like sustainable innovation, eco-innovation or sustainability-driven innovation. In the literature, we can see that the concept of eco-innovation was defined by James as "new products and processes which provide customer and business value but significantly decrease environmental impact" [25]. Sustainable innovation can be defined as "the development of new products, processes, services and technologies that contribute to the development and well-being of human needs and institutions while respecting the worlds' natural resources and regenerative capacity" [11]. Arthur D. Little [26] in his work defined the concept of "sustainability-driven innovation" as "the creation of new market space, products and services or processes driven by social, environmental or sustainability issues". As can be seen, the precise definition of sustainable innovation is very difficult to give, especially when there is not a precise definition for the sustainability and innovation concepts alone. Even if the concept of sustainable 
innovation is hard to clearly define, some characteristics seem to be universally accepted. One of these characteristics is that sustainable innovation is not just a new theoretical concept, but, as in case of innovation, it is about a more practical approach also, having a component of commercialization of the new technologies, products or services, and entrepreneurship.

\section{Methods and Materials}

When dealing with research that tries to extract data and text and the analysis of the citations of other studies, more often bibliometric review methods are used. These methods can provide a more extensive and complete analysis of the knowledge accumulated over time [27-29]. In the research of Corsini et al. [30], several reasons were identified as to why the adoption of bibliometric methods is the proper way to perform the research: (i) it is through these methods you can have an overview of the scientific literature; (ii) it is related to the third reason; and (iii) in case of traditional reviews, the output is a more subjective result of the selected scientific papers, while in the case of current times there is a shift towards more data studies than those subjective analyses. As a general working plan, the bibliometric method includes the selection of the papers in a sample database, filtering and refining the bibliographic data. In this process, we need to choose software and we need to decide how we want to visualize the information.

In the case of the management field, the researchers Zupic and Cater [28] have indicated a flow plan to map the scientific literature: (1) Research design, (2) compilation of bibliometric data, (3) analysis, (4) visualization, and (5) interpretation.

\subsection{Data Collection}

In order to have the overall proportion of the literature in the innovation field, the first collected data were related to the number of published articles indexed in the ISI Web of Science database. For this, we started the research by interrogating the ISI WoS database using the common keywords "innovation" and "sustainability", but also we searched the database for derivate keywords, like "business innovation", "sustainable development", and the two keywords at the same time, as "business innovation and sustainable development". In Table 1 we present the criteria and the filter that we used in our data collection. The main search filters used in the interrogation process were document type "article", then research years 2010-2019, and Web of science category business, management or economics. The search was done using the search interface of ISI WoS database, where we introduced the search criteria and selected to do the search in topic. According to the ISI WoS database, this means that the search is done in title, abstract, author keywords and a keywords plus tool. The keywords plus is a tool developed by the editors of the ISI WoS database to broaden the criteria search. The editors reviewed the titles of all references, and identified additional relevant but overlooked keywords that were not listed by the author or publisher. Using this tool, the search in the database revealed more papers that may not have appeared due to the changes in scientific words over time.

The initial search based on the general keywords indicated a large number of published articles having "innovation" or "sustainability" in their topic. Based on this initial conclusion, we decided that we needed to use an approach that can offer a better accuracy in determining the sample database. For this purpose, we used the guidelines of PRISMA, proposed by the researchers Moher, Liberati, Tetzla, \& Altman [31]. According to their research, the PRISMA approach indicates four steps to identify and extract the data for a bibliometric review (Figure 1).

The first step in the PRISMA approach is the identification of the article related to innovation and sustainability. In this phase, considering the large volume of published articles, we conducted the search in the ISI WoS database for articles having the keywords "innovation", "sustainability", "business innovation", "sustainable development", and "sustainable innovation" only in the title. In addition, articles containing "sustainability-oriented innovation", "innovation environmental", or "eco innovation" were included. In this phase of the research, we decided to add another filter to 
the interrogation process and we arranged the articles according to their number of citations in the ISI WoS database, and for each keyword we used the first 100 papers.

We conducted the initial literature search on February 22, 2020, and by using these filters we obtained a total of 652 journal articles published on our specific search. We limited the papers to only the ones written in English, and only those included in the article type papers. The limitation of the review to journal articles was done because peer-reviewed journal articles have a better degree of quality than other types of papers. We also performed a search in title, abstract and keywords, using the same criteria, in the Scopus database, as it is also one of the most important databases that covers very well the field of economic studies. This research indicated us another 54 important papers that we included in our sample database.

Table 1. Search criteria.

\begin{tabular}{ccc}
\hline & Search Criteria & Nb. of Articles \\
\hline Topic & "innovation" & 274,921 \\
Document type & article & 166,210 \\
Research years & $2010-2019$ & 121,402 \\
Web of Science Category & Business, management, economics & 41,883 \\
Topic & "sustainability" & 156,138 \\
Document type & article & 113,321 \\
Research years & $2010-2019$ & 93,339 \\
Web of Science Category & Business, management, economics & 12,924 \\
Topic & "business innovation" & 33,415 \\
Document type & article & 21,135 \\
Research years & $2010-2019$ & 26,360 \\
Web of Science Category & Business, management, economics & 14,390 \\
Topic & "sustainable development" & 126,714 \\
Document type & article & 79,141 \\
Research years & $2010-2019$ & 62,938 \\
Web of Science Category & Business, management, economics & 7213 \\
Topic & article & 2163 \\
Document type & "business innovation and substainable development" & 1265 \\
Research years & Business, management, economics & 1140 \\
Web of Science Category & & 450 \\
\hline
\end{tabular}

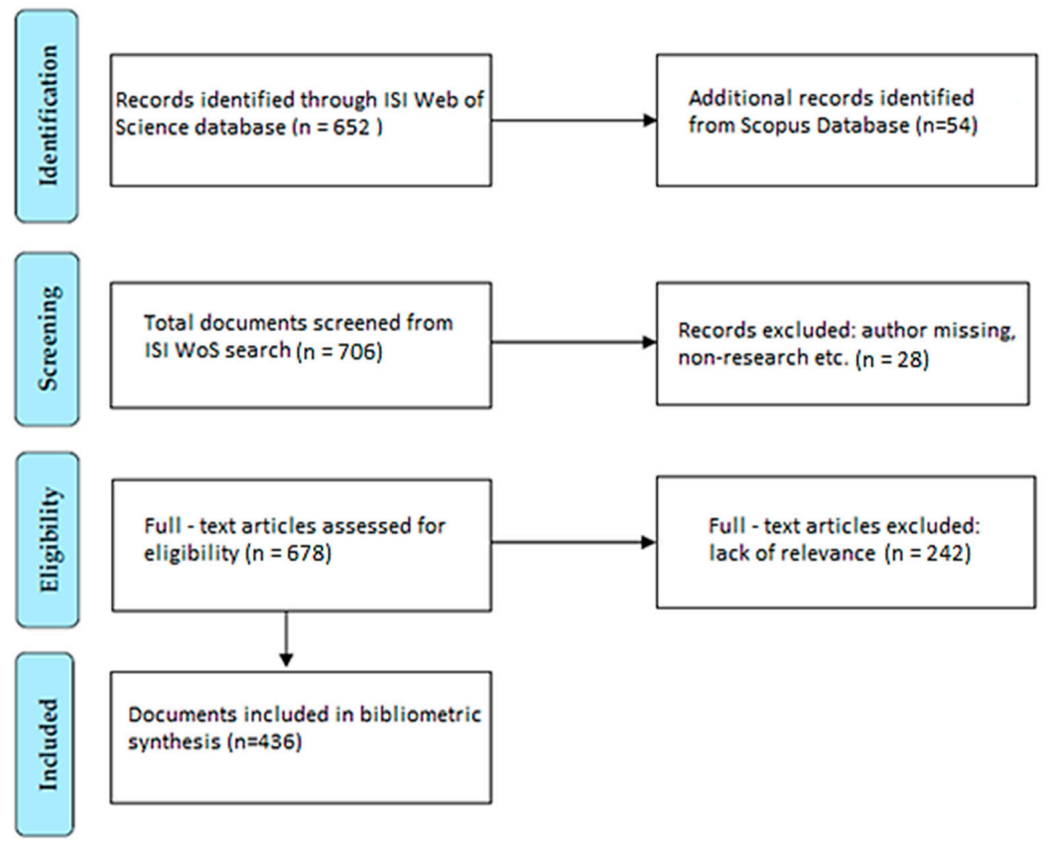

Figure 1. The PRISMA flow diagram used to identify, screen and include papers for our bibliometric review. 
In the next step, we eliminated documents without author names, documents identified as book chapters, as well as documents that have the subject area other than business, economics and management. Moreover, we eliminated the articles without keywords such as innovation, sustainability, sustainable innovation, innovation management, and so on. In this step, we eliminated 28 articles, leaving a database of 678 articles.

Then, from the selected papers, we first identified and removed the duplicates, i.e., studies that were returned from both databases. In the next step, the remaining papers were studied by reading their title and abstract, and evaluating if they corresponded to the purpose of this research. Many of the articles were removed from this study because they were from other fields of study, like ecology or green technology, that are not the subject of this research. Other articles just mentioned sustainability or innovation, but they had different goals, so these articles were excluded. The result of this process indicated a database of 436 peer-reviewed journal articles.

\subsection{Data Extraction}

The final database, consisting of 436 journal articles, was exported in a file format that was supported by the used software. In this research, we chose VOSviewer software for data analysis. The program is freely available to the bibliometric research community, and unlike most computer programs that are used for bibliometric mapping, VOSviewer pays special attention to the graphical representation of bibliometric maps. The functionality of VOSviewer is especially useful for displaying large bibliometric maps in an easy-to-interpret way. VOSviewer runs on a large number of hardware and operating system platforms, and can be started directly from the internet [32]. The main data retrieved from the final database includes information related to the article title, the author names, the used keywords and citation information, including the reference lists of all articles. For better accuracy of the research results, the initial downloaded database was manually analyzed and processed. The co-citation analysis performed by VOSviewer software was conditioned by a certain uniformity of the format information, for example, the name of the journals should have the same format. In this sense, a big part of the research was dedicated to this data standardization.

\subsection{Data Analysis}

Descriptive analyses were conducted in the first phase. Using Excel, we generated a series of graphs to identify a path related to the evolution in time of the published papers on innovation and sustainability concepts. In the next phase we used the bibliometric analysis methodology. This methodology utilizes citations to identify the most valuable papers, researchers or journals within a certain domain. By citation analysis, we can identify the number of times a paper has been cited by another article in the index from which it came. We can use also other citation metrics, like h-index, total citations and citation per article; all this indicates a certain scholarly influence of the researchers in the field.

Another method of getting insights into the scholarly influence is the co-citation analysis [33,34]. The researchers Zupic and Cater [28] explain co-citation as "the frequency with which two units (authors, journals, and documents) are cited together". The purpose of co-citation analysis is to develop a measurable way of analyzing the similarity between papers, authors or journals.

Depending on the desired result, the co-citation analysis can focus on journal co-citation, author co-citation, keyword co-citations and so on. These co-citation matrices serve as the basis for analytical techniques such as multi-dimensional scaling (MDS) and visualization of similarities (VOS) through bibliometric mapping [27]. For this paper, we used the VOSviewer software, that allowed us to create visual representations or 'network maps' of the relationships between data of the papers included in our sample database. 


\section{Research Results}

\subsection{Volume of Published Articles on Innovation and Sustainability}

For a better scale of the literature in the innovation and sustainability fields of study, we generated two graphs (Figure 2), in which can be seen the evolution in time of the number of published articles related to the two concepts. Given the large number of articles published in recent years, we have grouped the years of publication over several intervals. Thus, the considered intervals were: articles published until 1990, between 1991 and 2000, between 2001 and 2010, and from 2011 until 2019. We maintain the same filter described in Table 1 from the data collection section of the paper.
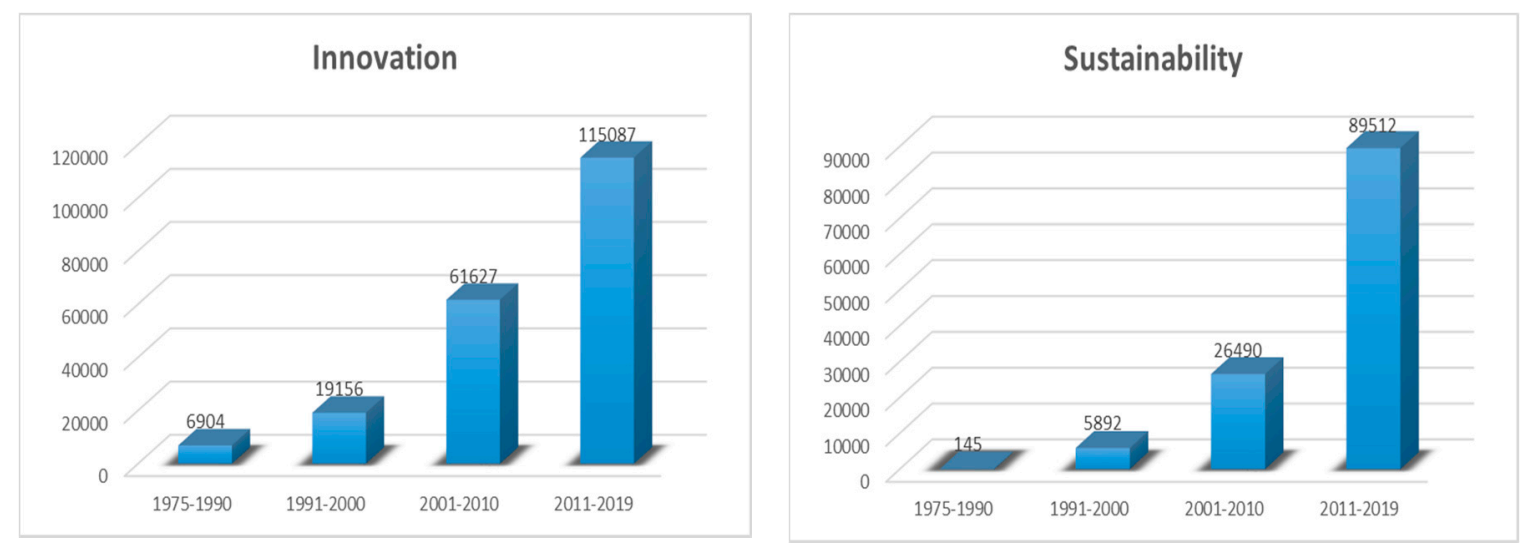

Figure 2. The published time evolution of the articles, having the topics innovation and sustainability, respectively.

The data from the graphs indicate quite clearly that the two concepts, of innovation and sustainability, are gaining major importance in recent years. In both cases, the data indicate that there is an increasing number of published articles. Furthermore, in both cases, there is a big difference in the number of articles published in the last 10 years-115,087 in the innovation case, and 89,512 in the case of sustainability—compared to the total number of articles published before 2011: 87,687 articles on innovation and 32,527 on sustainability.

Given the large number of articles for further analysis, we used other filters to limit the volume of papers. The first filter was to limit the research just to the areas of business, management and economics. The next limitation was on articles published from 2010 up to 2019 inclusively. The last filter was to interrogate the ISI WoS database for articles that have innovation and sustainability in their title. In Figure 3, we present the evolution of the published articles containing innovation and sustainability, respectively, in their titles.

We can observe that the trend in the number of published articles is the same as in the general case: the number of articles is increasing each year. In absolute terms, the articles having innovation in their titles increase from 878 in 2010 up to 2214 in 2019, and the articles having sustainability in their title increase from 196 in 2010 up to 606 in 2019.

\subsection{Journals Analysis of Sustainable Innovation Articles}

The next research direction was to analyze the composition of the papers included in the sample database according to their publishing source. In Table 2, we present the first 15 journals according to the number of published articles. When we analyzed the total number of articles from the sample database, we identified that $58 \%$ of the total articles are published in the 15 most highly cited journals. As an absolute number, we identified 251 out of 436 papers published in the top 15 journals. 

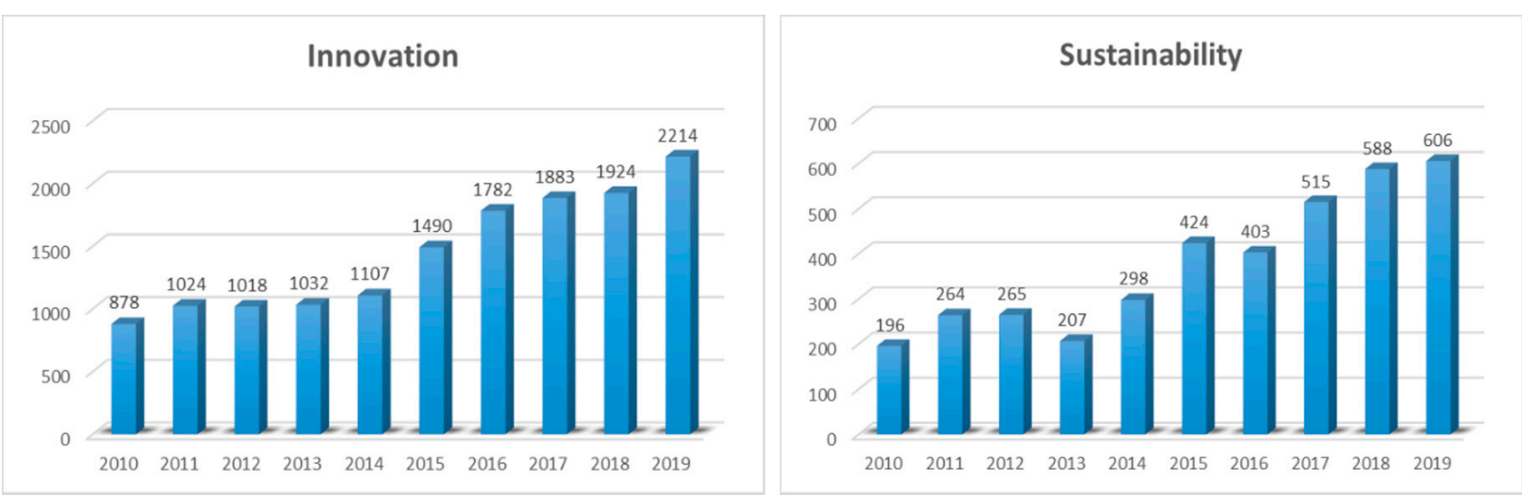

Figure 3. The number of published articles having innovation and sustainability, respectively, in their titles, in the period 2010-2019.

Table 2. Top 15 journals with the most published articles on innovation and sustainability.

\begin{tabular}{ccc}
\hline Nr.crt & Journal Name & Article No. \\
\hline $\mathbf{1}$ & Sustainability & 81 \\
$\mathbf{2}$ & Journal of Cleaner Production & 55 \\
$\mathbf{3}$ & Technological Forecasting And Social Change & 22 \\
$\mathbf{4}$ & Business Strategy and the Environment & 13 \\
$\mathbf{5}$ & Technology in Society & 8 \\
$\mathbf{6}$ & Journal of Technology Management and Innovation & 7 \\
$\mathbf{7}$ & Technovation & 7 \\
$\mathbf{8}$ & Journal of Security and Sustainability Issues & 6 \\
$\mathbf{9}$ & Research Policy & 6 \\
$\mathbf{1 0}$ & Sustainable Development & 6 \\
$\mathbf{1 1}$ & Environmental Innovation And Societal Transitions & 5 \\
$\mathbf{1 2}$ & Research Technology Management & 5 \\
$\mathbf{1 3}$ & Corporate Social Responsibility And Environmental Management & 4 \\
$\mathbf{1 4}$ & Global Environmental Change & 4 \\
$\mathbf{1 5}$ & International Journal Of Innovation And Sustainable Development & 4 \\
\hline
\end{tabular}

Data presented in Table 2 reveal that the journal with the highest number of published articles is the journal Sustainability, which, according to their site, is "an international, cross-disciplinary, scholarly, peer-reviewed and open access journal of environmental, cultural, economic, and social sustainability of human beings. Sustainability provides an advanced forum for studies related to sustainability and sustainable development" [35]. The second journal having a consistent number of articles in the field of sustainable innovation is the Journal of Cleaner Production, which is "an international, transdisciplinary journal focusing on Cleaner Production, Environmental, and Sustainability research and practice. The journal serves as a platform for addressing and discussing theoretical and practical cleaner production, encompassing environmental, and sustainability issues in corporations, governments, education institutions, regions, and societies" [36].

For the next analysis, we computed a journal co-citation analysis map, presented in Figure 4. The co-citation map is formed by a series of bubbles or nodes which have the purpose of indicating the relative number of co-citations for a certain journal. According to their co-citation frequency, the journals are located closely together [28]. This indicates that there is a series of similarities in the content of articles. Other information on the map is offered by a series of lines that represent the links of co-citation between articles published in other journals. For better visualization of the data, colors are used, so each node has a color that corresponds to articles published in related journals based on their co-citation frequency. This means that all the journals sharing the same color have similarities in their content [37]. 


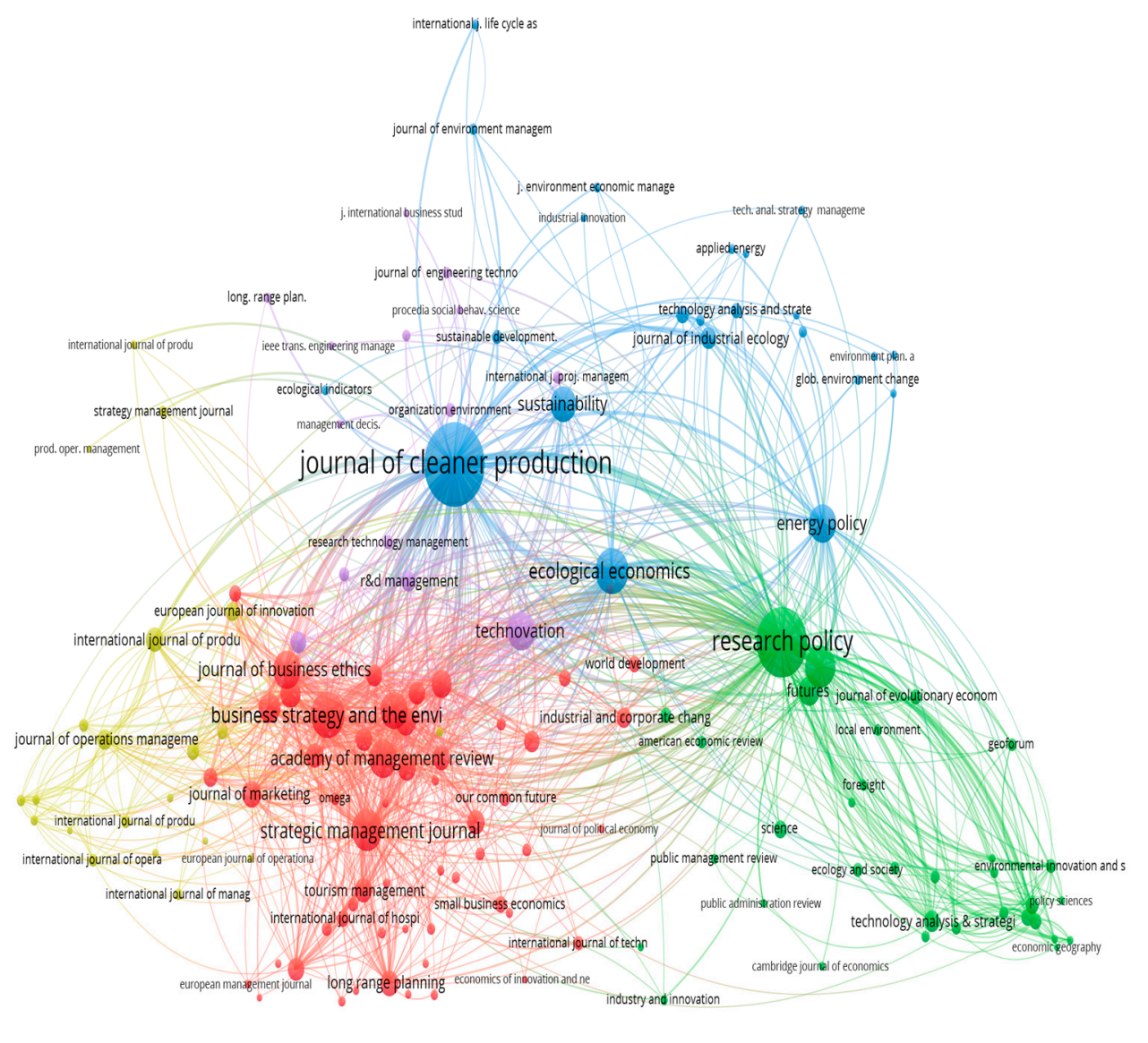

屌VOSviewer

Figure 4. The co-citation network analysis of journals.

In our sample of 436 articles, a total of 11,117 sources were identified, and the minimum number of citations of a source was set to 10, resulting in a number of 231 articles that met the threshold, among which 150 articles were displayed in Figure 4. The size of the node indicates the number of citations received, meaning that the bigger the node, the greater the number of citations for that journal. The principle of similarity applies in the distribution of the nodes, so that the similar nodes are grouped together.

The journal co-citation analysis generated five distinct and coherent clusters of journals on the network map. The biggest cluster, formed by 56 items, is the red cluster, and several journals stand out. In this cluster, we can observe a set of journals tightly grouped as important. The journal with the biggest number of direct citations, 334, is Business Strategy and the Environment, which has a total link strength of 11,395. Another journal that stands out is the Strategic Management Journal, with 271 direct citations and a total link strength of 10,909. Journal of Business Ethics is another important journal from the cluster, with 215 direct citations and a total link strength of 7530. Academy of Management Review has 213 direct citations and a total link strength of 7660.

The second cluster by the number of items is the green one, with 34 items. In this cluster, the journal Research Policy is the one that is the most visible, having 727 direct citations and a total link strength of 22,517. Another journal from this cluster is Technological Forecasting and Social Change, with 271 direct citations and a total link strength of 8759. Futures is another journal from the green cluster, which has 131 direct citations and a total link strength of 3604 .

The third cluster by the number of items, 23, is the blue cluster. Even if it is the third cluster by the number of items, in this cluster we have the journal that stands out from the entire map, the Journal of Cleaner Production, with 1052 direct citations and a total link strength of 25642. Other important 
journals from this cluster are: Ecological Economics, with 310 direct citations and a total link strength of 8598; Energy Policy, with 215 direct citations and a total link strength of 6239; Sustainability, with 191 direct citations and a total link strength of 3598.

The fourth and the fifth clusters group the journals with less cited papers. The fourth cluster, the yellow one, has 21 items, among which we mention the International Journal of Production Economics, with 93 direct citations and a total link strength of 3731. The fifth cluster is the purple one, which groups 14 items, among which the Technovation journal stands out, having 226 direct citations and total link strength of 7539 .

\subsection{Influential Authors and Articles in the Sustainable Innovation Field}

In order to find the most prominent papers in our sample database, we performed a citation analysis. The principle of the analysis is that the higher the number of citations for a paper, the higher is its influence in the research field [37]. In Table 3 we presented the top 15 papers according to their number of citations. The number of citations is received from the interrogation of the ISI WoS database; this reflects citations to source items indexed within the Web of Science Core Collection.

Table 3. Top 15 most cited papers.

\begin{tabular}{|c|c|c|c|c|}
\hline $\mathbf{R}$ & Article Title & Authors & Year & TC \\
\hline 1 & Sustainability transitions: An emerging field of research and its prospects & Markard, J., Raven, R., Truffer, B. & 2012 & 772 \\
\hline 2 & $\begin{array}{l}\text { Business models for sustainable innovation: State-of-the-art and steps towards a } \\
\text { research agenda }\end{array}$ & Boons, F., Lüdeke-Freund, F. & 2013 & 513 \\
\hline 4 & Toward a spatial perspective on sustainability transitions & Coenen, L., Benneworth, P., Truffer, B. & 2012 & 375 \\
\hline 5 & $\begin{array}{c}\text { Growing grassroots innovations: Exploring the role of community-based initiatives in } \\
\text { governing sustainable energy policy transitions }\end{array}$ & Seyfang, G., Haxeltine, A. & 2012 & 329 \\
\hline 6 & Sustainable innovation, business models and economic performance: An overview & $\begin{array}{l}\text { Boons, F., Montalvo, C., Quist, J., } \\
\text { Wagner, M. }\end{array}$ & 2013 & 278 \\
\hline 7 & $\begin{array}{l}\text { Corporate sustainability and innovation in SMEs: Evidence of themes and activities in practice } \\
\text { Legitimizing research, technology and innovation policies for transformative change: }\end{array}$ & Bos-Brouwers, H.E.J. & 2010 & 230 \\
\hline 8 & $\begin{array}{l}\text { Combining insights from innovation systems and multi-level perspective in a comprehensive } \\
\text { 'failures' framework }\end{array}$ & Weber, K.M., Rohracher, H. & 2012 & 224 \\
\hline 9 & Environmental Innovation and Sustainability Transitions in Regional Studies & Truffer, B., Coenen, L. & 2012 & 213 \\
\hline 10 & A value mapping tool for sustainable business modelling & $\begin{array}{l}\text { Bocken, N., Short, S., Rana, P., Evans, } \\
\text { S. }\end{array}$ & 2013 & 169 \\
\hline 11 & $\begin{array}{l}\text { Sustainable consumption within a sustainable economy-Beyond green growth and } \\
\text { green economies }\end{array}$ & Lorek, S., Spangenberg, J.H. & 2014 & 163 \\
\hline 12 & $\begin{array}{c}\text { Success factors for environmentally sustainable product innovation: A systematic } \\
\text { literature review }\end{array}$ & $\begin{array}{l}\text { De Medeiros, J.F., Ribeiro, } \\
\text { J.L.D.,Cortimiglia, M.N. }\end{array}$ & 2014 & 161 \\
\hline 13 & $\begin{array}{l}\text { Critical factors for implementing and diffusing sustainable product-Service systems: Insights } \\
\text { from innovation studies and companies' experiences }\end{array}$ & Ceschin, $\mathrm{F}$. & 2013 & 158 \\
\hline 14 & The adoption of sustainable innovations: Driven by symbolic and environmental motives & $\begin{array}{l}\text { Noppers, E.H., Keizer, K., Bolderdijk, } \\
\text { J.W., Steg, L. }\end{array}$ & 2014 & 152 \\
\hline 15 & Adopting sustainable innovation: What makes consumers sign up to green electricity? & Ozaki, R. & 2011 & 150 \\
\hline
\end{tabular}

Abbreviations: R-rank; TC—total citations.

The data from Table 3 indicate that the paper "Sustainability transitions: An emerging field of research and its prospects", written by Markard J., Raven R., and Truffer, B. [38], is the most cited article in the field of sustainable innovation. The paper was published in 2012, in Research Policy journal, and it has 772 citations in the ISI Web of Science database. The authors of this paper address the subject of sustainability-oriented innovation, and they conducted a review of basic conceptual frameworks, together with bibliographical analysis of 540 journal articles in the field.

The second most cited paper is "Business models for sustainable innovation: State-of-the-art and steps towards a research agenda", published in Journal of Cleaner Production, written by Boons Frank and Lüdeke-Freund F [3], with 479 citations on ISI Web of Science. In this paper, the authors approach from a business model perspective, and propose examples of normative requirements that business models should meet in order to support sustainable innovations.

From the author co-citation point of view, in Figure 5 we present the author co-citation map, based on 26,000 authors, of which 161 authors met the threshold of having a minimum number of 20 citations. Figure 6 displays the 100 most frequently co-cited authors in a network map. The author co-citation analysis groups authors into clusters on a network map based on the similarity of their 
co-citations $[33,39]$. The interpretation of the authors co-citation map is done using the same guidelines listed for the journals co-citations map.

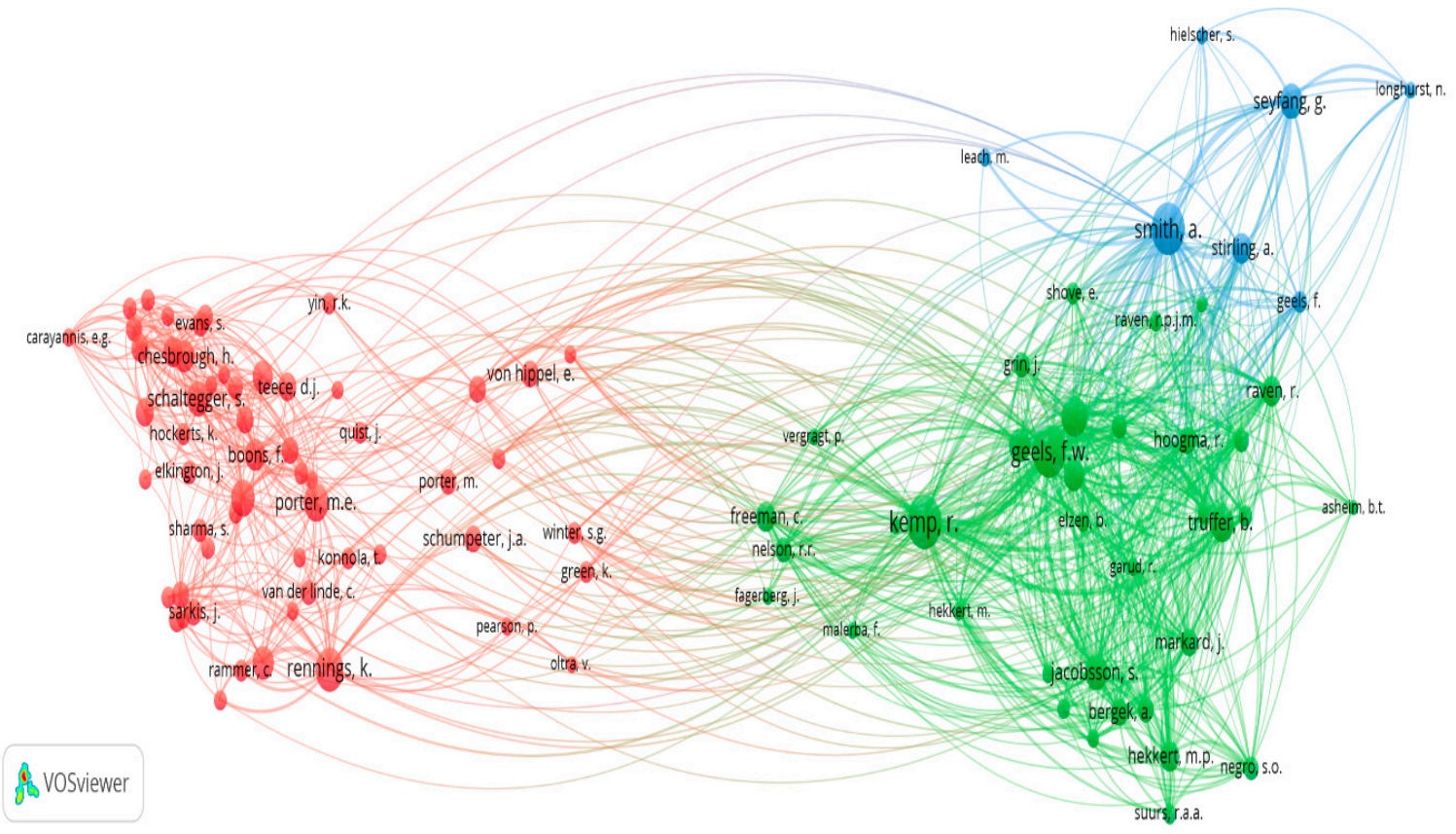

Figure 5. The author co-citation map.

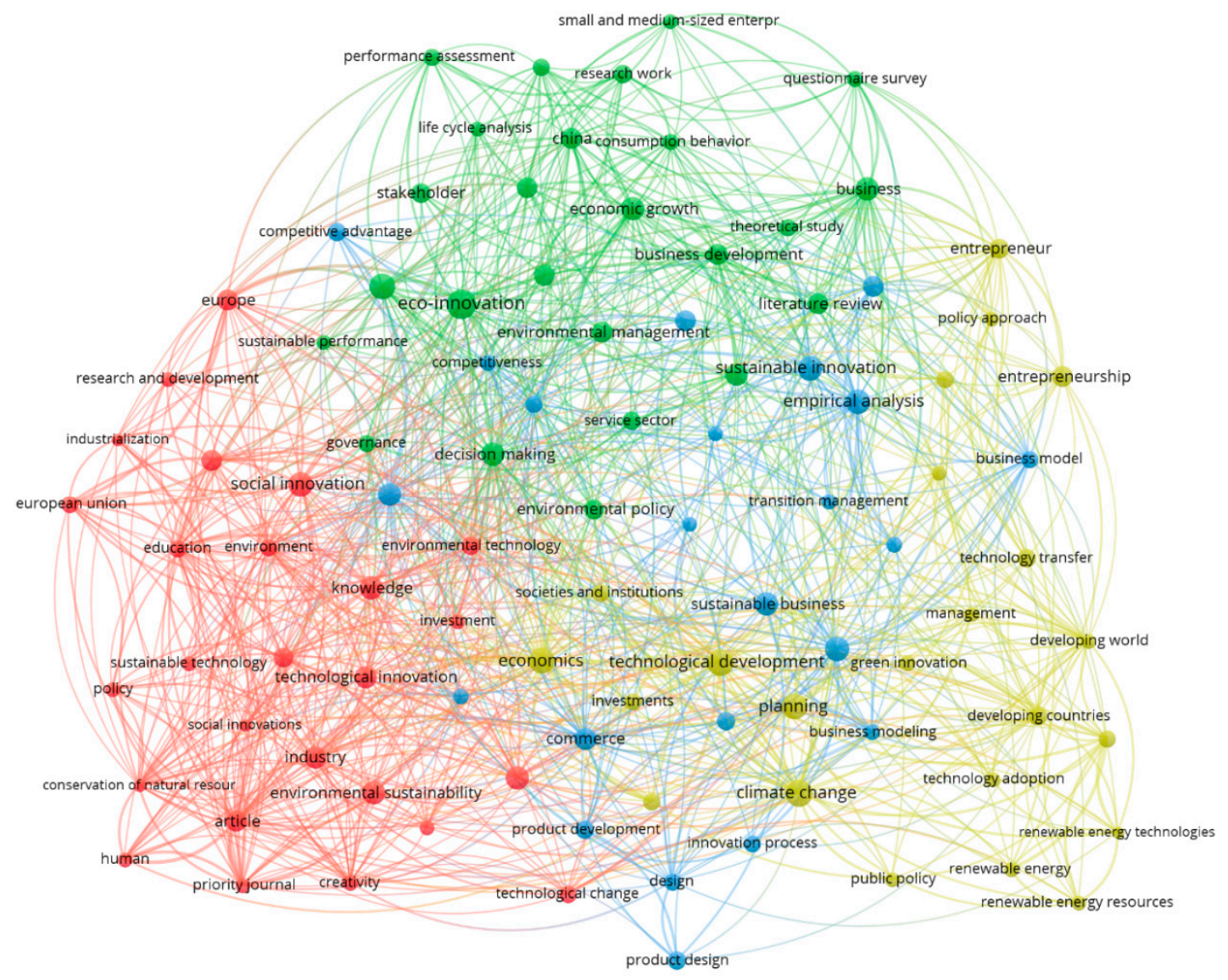

Figure 6. The keyword co-occurrence network map. 
In the authors co-citation map, three main clusters were identified. The red cluster is the biggest one, having 57 authors, among which we can identify one author that stands out, the researcher Boons Frank from Vanderbilt University, Nashville, United States, having a total link strength of 1933 and 76 direct citations. Boons is also present with 2 papers in the top 15 papers according to the number of citations (Table 3). Another researcher that is present as coauthor of 2 papers in the top 15 papers is Wagner Marcus from Universität Hohenheim, Stuttgart, Germany. He has 100 direct citations and a total link strength of 2483. Of 1 of the papers from top 15, he is coauthor with Boons F. Another coauthor of Wagner M. is Schaltegger Stefan, from Leuphana Universität Lüneburg, Luneburg, Germany, which is one of the names that stand out in the red cluster. He has 93 direct citations and a total link strength of 2117.

The second cluster by size is the green cluster, containing 36 authors. In this cluster, there are quite obviously three authors that stand out. One of them is Kemp Rene from Maastricht University, Maastricht, Netherlands, who has 212 direct citations and a total link strength of 9585 . Another researcher that stands out from the green cluster is Geels Frank from University of Manchester, who has 204 direct citations and a total link strength of 9938. One of the researchers who is the coauthor of 3 papers in the top 15 papers by number of citations from our sample database is Truffer Bernhard from Swiss Federal Institute of Aquatic Science and Technology, Dubendorf, Switzerland. He has 108 direct citations and a total link strength of 7335 .

The third cluster, the blue one, is comprised of seven authors. The author Smith Adrian from the University of Sussex, United Kingdom, is the author that stands out. He has 198 direct citations and a total link strength of 7909. Another researcher in this cluster is Seyfang Gill from University of East Anglia, Norwich, United Kingdom, who has 95 direct citations and a total link strength of 2800.

\subsection{The Topical Focus in the Sustainable Innovation Field}

The next research direction was to perform a keyword co-occurrence analysis (Figure 6). The purpose of this analysis is to identify frequently studied topics in the sustainable innovation field, and also to highlight their relationship. The rationale behind a keyword co-occurrence analysis is explained by the researchers Zupic and Cater [28], who state that "When words frequently co-occur in documents, it means that the concepts behind those words are closely related. The output of the co-word analysis is a network of themes and their relations that represent the conceptual space of a field" (p. 435). By performing the keyword co-occurrence analysis, we can identify which combination of keywords is often used by authors; this can also indicate trends and patterns in the studied topics [40,41].

The generation of the keywords co-occurrence map was made based on 2604 keywords found in the 436 papers from the sample database. We established a limit of a minimum of five occurrences of the keyword to be included in the results, and a number of 173 papers met the threshold. The keyword co-occurrence analysis also offers important insight regarding other rising topics related to the studied area [42]. For a better overview of the emerging topics, we removed the top three keywords from the map, namely "innovation", "sustainable development" and "sustainability", due to their extremely frequent co-occurrence (276 cases for innovation, 260 cases for sustainable development and 201 cases for sustainability). The main aspect visualized in the keyword co-occurrence map regards the occurrence of the keywords based on their prevalence and the evolution in time of their popularity $[28,43,44]$.

The VOS viewer software generated four clusters for the keyword occurrence analysis. The size of the clusters is almost the same; the difference between the biggest cluster, the red one, and the next cluster, the green one, is only 1 item-26 items for the red clusters and 25 items for the green cluster. The other two clusters have the same number of items, with only one item less than the green one. In the red cluster, we can identify keywords like "social innovation", having an occurrence of 17 times and a total link strength of 69. Another keyword in the red cluster is "technology innovation", with an occurrence of 14 and the total link strength of 63. "Environmental sustainability" is a keyword that has an occurrence of 15 and a total link strength of 47 . 
In case of the green cluster, the main keywords are "eco innovation", occurrence of 25 and total link strength of 36; "environmental management", occurrence 13 and total link strength 36; "business development", occurrence 13 and total link strength of 44 . From the blue cluster we can highlight "sustainable innovation", occurrence 17 and total link strength 38; "sustainable business", occurrence 15 and total link strength of 48; "business model innovation", occurrence 17 and total link strength 53. In the last cluster, the yellow one, the keywords that stand out are: "technological development", total link strength 104 and occurrence 21; "planning", total link strength 67 and occurrence 20; and "climate change", total link strength 75 and occurrence 21.

\section{Discussion and Conclusions}

The main purpose of the research was to identify common points and future interdisciplinary researches between innovation and sustainability, by empirically documenting the intellectual structure, the volume, and the knowledge-development directions. For fulfilling these purposes we used a bibliometric analysis, and we analyzed 436 papers published in journals indexed in ISI WoS. In this section of the paper, we conclude the obtained results and offer the main limitations and future research directions.

\subsection{Interpretation and Implications of the Research Results}

The first research question addressed in this study is related to the identification of the evolution of the volume of published articles. The initial conclusions reveal similarities in the evolution of the number of articles in the cases of innovation and sustainability topics. Even if the concepts are not new (we identified articles starting from 1975), in both cases, in the last 10 years, from 2010 to 2019 , the volume of the published papers increased substantially compared to the previous periods. In the case of innovation, the volume of published articles doubled in the last 10 years, compared to the entire previous period of 35 years, starting in 1975. The evolution of the volume of published articles in the case of the sustainability concept is more pronounced: in the last 10 years, the number of articles has increased four times compared to the whole previous period of 35 years. If we compare the values, we can say that the researchers' interest in innovation doubled in the last years, and in the case of sustainability the interest is four times bigger. This conclusion is obviously not based on solid ground, it is just an initial evaluation of the size of the literature having innovation and sustainability, respectively, in the topics of the articles. If we analyze the absolute values of the data, we can observe that in both cases, the output of the research reveals more than 100,000 articles just in the last 10 years in the case of innovation, and almost 100,000 articles for sustainability.

For better analysis of this evolution, we focused attention on the articles published in the last 10 years, from 2010 to 2019, and by introducing new filters we decreased the total number of articles to only the articles that have innovation or sustainability in their titles. In this new configuration, we can still observe an increase in the number of articles from year to year. Regarding the absolute values, we identify that the evolution of the published articles starts from 878 articles in 2010 up to 2214 published in 2019 in the case of innovation, and from 196 articles in 2010 up to 606 in 2019 in the case of sustainability. There is an obvious difference in the absolute values of the total published articles on innovation-114,352 articles-and on sustainability-only 2766 - but if we analyze the increase of the published articles as a percentage, we can observe similar percentages in both cases: around $70 \%$ increase in the number of articles in the period 2010 up to 2019. This indicates more future similarities in the evolution of the volume of papers in both cases.

This evolution can have different factors, one of them can being the globalization of the economy that forced organizations to find new ways of surviving and thriving; in this sense, innovation is a solution [45]. Besides innovation, society is more and more aware of the environmental problems, and thus the sustainability concept is more present $[46,47]$. In this context, some new dimensions of the research emerge, and among sustainable development there is the premises of integrating the two concepts into a new concept of "sustainable innovation". 
Having this first conclusion, we approach the second research question, in order to identify what are the most influential journals, authors and papers in the two research fields. In order to respond to this question, we performed a bibliometric analysis of the literature. In this case we needed to establish a sample database containing articles from both fields of research. Given the big number of published articles in the last 10 years, the filters used so far were not enough, and we decided to use another filter and analyze only the top 100 papers according to their number of citations from each research criteria. The number of citations was received from the interrogation of the ISI WoS database; this reflects citations to source items indexed within Web of Science Core Collection. For a better coverage of the published papers in the two studied fields in forming the sample database, we added more search criteria beside innovation and sustainability, as explained in the data collection section of the paper. In the end, our sample database was formed by 436 articles. By conducting the bibliometric analysis, we identified that from the journals point of view, the journals with the highest number of published papers is the journal Sustainability. The second journal by number of publications is Journal of Cleaner Production. Technological Forecasting and Social Change and Business Strategy and the Environment are other journals that have a lot of papers in the sustainable innovation topic.

We analyzed also the journals from the influential point of view, and we generated a journal co-citation map. The journal citation analysis and document co-citation analysis together clearly demonstrate the multi-disciplinary nature of the articles included in the sample database. The review identified one major influential journal that specifically targets environmental and sustainability research, namely Journal of Cleaner Production. Notably, this journal occupied central positions in this multi-disciplinary field. However, remarkably, the most influential articles were all published in top field journals such as the Research Policy, Ecological Economics, Sustainability, Business Strategy and the Environment or Technological Forecasting and Social Change. It can be also observed that, if we look at the journals with the most published articles in our database, and the most influential journals according to the co-citation map, they are the same. These results suggest potential publishing venues for scholars in this research area. As a final observation, judging from the journal co-citation point of view, the Journal of Cleaner Production is the most influential journal in this field of study. Furthermore, other journals stand out, like the Sustainability, Research Policy, Ecological Economics, Energy Policy or Business Strategy and the Environment journals, which have a greater number of published articles.

The intellectual structure, or the most cited works and authors in the studied field of the research, was the next direction that we focused our attention in. An important feature of science mapping is its ability to identify the top articles that have a significant role in the scientific literature. By analyzing their contribution to the research field, we can identify the origin of the field and reveal its theoretical foundation. Our co-citation analysis revealed the paper "Sustainability transitions: An emerging field of research and its prospects", written by Markard J., Raven R., and Truffer, B. [38] as the most cited article in the field of sustainable innovation. The second most cited paper is "Business models for sustainable innovation: State-of-the-art and steps towards a research agenda", written by Boons F. and Lüdeke-Freund F [3]. The research in the sustainable innovation field is oriented towards several perspectives, like the sustainability transitions process [48-53]. Another perspective is given by the approach of transition to sustainability with the help of innovation [54-57]. Other authors approach with the perspective of developing models for sustainable innovation [3,58-61]. The learning perspective was also approached by some of the authors [62-65].

For the most influential authors in the field, an author co-citation map was generated, identifying three distinctive clusters. From the biggest clusters some important authors are Boons Frank, Wagner Marcus or Schaltegger Stefan, who have also worked together and developed the connection between the innovation and sustainability fields of research. They also have articles included in the top 15 most citied ones. Other important researchers in the field are Kemp Rene and Geels Frank, who both are professors of innovation and sustainable development, and have important papers that contributed to the increase of knowledge in the field. Truffer Bernhard or Smith Adrian are two other researchers whose studies have been validated by researchers via references to their articles. 
It is interesting to observe that the author co-citation map reveals authors that are not present in the top 15 most cited papers. This can be explained by the methodology of generating the co-citation map and the process of selecting the top 15 most cited papers. In case of the most cited papers, the classification is done according to the results offered by the ISI WoS database, which summarizes all the citations to source items indexed within Web of Science Core Collection, while the co-citation map is created by analyzing the articles included in sample database. The condition to be included in the map is a minimum of 20 citations, but in this case the citations are gather from the total articles in our sample database, so it is possible that an article indicated as highly cited by the ISI WoS database is not so cited in our sample database. In conclusion, in analyzing the most influential authors that address the combination of the concepts of innovation and sustainability, we need to take into consideration the limitations of any research, but it is clear that the work of the above authors must be analyze among other valuable works.

The final part of our research addressed the most research topics in the studied field, and for this we performed a keyword co-occurrence analysis and generated a keyword co-occurrence map, identifying four distinctive clusters. In order to have a better image of the emerging research topics, we decided to eliminate from the map the three most used keywords: innovation, sustainability and sustainable development. The first observation is that the size of the clusters is very similar, the difference being one keyword. From the identified clusters a series of keywords stand out, and in this way some potential directions in the field were identified. In the first cluster we mention "social innovation", with a series of papers like [66-69]. Other directions of research are "technology innovation" [70-73] and "environmental sustainability" [74-76], from the first cluster. In the second cluster, we can identify keywords like "eco-innovation" [77-81], "environmental management" [62] or "business development" [63]. In the emerging directions of research, we can identify even the keyword "sustainable innovation", which is the main subject of this paper, but the keyword co-occurrence analysis highlights that it is still in the phase of an emerging source of research, being less important than "innovation" or "sustainability". In the third cluster we can identify keywords like "sustainable businesses" [64,65,82-85] or "business model innovation" [82,85-89]. Lastly, from the fourth cluster we can identify "planning" [89,90] and "climate change" [91,92].

As a general conclusion, we can say that the fields of innovation and sustainability have a lot of similarities in their evolution, and combining the main aspects of both concepts in a single concept like "sustainable innovation", as can be seen from the keyword co-occurrence analysis, can be an emerging topic of research, offering new research directions in a very big field of innovation and a new and actual field of sustainability. If we consider the international regulations related to environmental protection in the last years, the global concern related to the use of natural resources, or the ever-more competitive business environment, we can have a clear image showing that, in order to be competitive, besides quality, innovation or environmental protection, organizations need to also implement the sustainability requirements. In this context, innovation oriented towards sustainability or sustainable innovation can be a solution to this new requirement.

\subsection{Limitations and Future Research}

The interpretations of the results obtained from the research are conditioned to a series of limitations. One limitation is given by the fact that science mapping provides a systematic, quantitative approach to analyzing the structure of a knowledge base. However, given its focus on 'meta-data' associated with documents comprising a body of knowledge, science mapping does not replace review methods that analyze substantive findings extracted from research papers. Considering this limitation, we need to point out that the current review only sets the stage for subsequent research syntheses that examine findings from studies of sustainable innovation.

Another limitation is given by the forming of the sample database. During the search phase, we relied on multiple sets of keywords (i.e., sustainability, innovation, sustainable development) to identify documents for inclusion. This approach employed the assumption that if authors of the 
documents were adopting a 'sustainability perspective' on their exploration of a particular subject, this would be captured in the keywords included either in the title, author-assigned keywords, or the abstract. Even if we performed an article-by-article reading of more than 600 papers and reduced the sample to just 436 papers, there is the possibility of not including in the sample database some other valuable perspective.

In the end, we need to highlight that despite the quantitative rigor of bibliometric analysis, the interpretation of co-citation maps is not always straightforward. Arriving at the suitable threshold for co-citation analysis can also be challenging. Thus, Zupic and Cater [28] observed that 'making sense' of the output of co-citation analyses requires the scholar to already possess a relatively firm knowledge of the literature. We can conclude that a new field that combines the concepts of innovation and sustainability is rapidly developing, that we can identify some passionate researchers, and that we have the possibility, through scientific journals, to pass on the knowledge so that the whole society will thrive.

Author Contributions: D.M. is the leading author of this study. A.M. contributed significantly to the study design, the conceptual analysis for the initial framework used in this review, the synthesis of the results and final writing of the review. I.A., L.A. and O.G. were involved in the overall supervision of the systematic literature review. All authors read carefully and approved the final version of the manuscript.

Funding: This research received no external funding.

Conflicts of Interest: The authors declare no conflict of interest.

\section{References}

1. Bessant, J.; Tidd, J. Innovation and Entrepreneurship; John Wiley \& Sons Ltd.: Hoboken, NJ, USA, 2007.

2. Chesbrough, H. Open innovation: How companies actually do it. Harv. Bus. Rev. 2003, 81, 12-14. [PubMed]

3. Boons, F.; Luedeke-Freund, F. Business models for sustainable innovation: State-of-the-art and steps towards a research agenda. J. Clean. Prod. 2013, 45, 9-19. [CrossRef]

4. Silvestre, B.S. Sustainable supply chain management in emerging economies: Environmental turbulence, institutional voids and sustainability trajectories. Int. J. Prod. Econ. 2015, 167, 156-169. [CrossRef]

5. Aboelmaged, M.; Hashem, G. Absorptive capacity and green innovation adoption in SMEs: The mediating effects of sustainable organisational capabilities. J. Clean. Prod. 2019, 220, 853-863. [CrossRef]

6. Behnam, S.; Cagliano, R.; Grijalvo, M. How should firms reconcile their open innovation capabilities for incorporating external actors in innovations aimed at sustainable development? J. Clean. Prod. 2018, 170, 950-965. [CrossRef]

7. WCED. Report of the World Commission on Environment and Development: Our Common Future; WCED: New York, NY, USA, 1987.

8. Jacobsson, S.; Bergek, A. Innovation system analyses and sustainability transitions: Contributions and suggestions for research. Environ. Innov. Soc. Transit. 2011, 1, 41-57. [CrossRef]

9. Geels, F.W. The multi-level perspective on sustainability transitions: Responses to seven criticisms. Environ. Innov. Soc. Transit. 2011, 1, 24-40. [CrossRef]

10. van Kleef, J.A.G.; Roome, N.J. Developing capabilities and competence for sustainable business management as innovation: A research agenda. J. Clean. Prod. 2007, 15, 38-51. [CrossRef]

11. Baumann, H.; Boons, F.; Bragd, A. Mapping the green product development field: Engineering, policy and business perspectives. J. Clean. Prod. 2002, 10, 409-425. [CrossRef]

12. Melane-Lavado, A.; Álvarez-Herranz, A. Different ways to access knowledge for sustainability-oriented innovation. The effect of foreign direct investment. Sustainability 2018, 10, 4206. [CrossRef]

13. Ghassim, B.; Bogers, M. Linking stakeholder engagement to profitability through sustainability-oriented innovation: A quantitative study of the minerals industry. J. Clean. Prod. 2019, 224, 905-919. [CrossRef]

14. Nidumolu, R.; Prahalad, C.K.; Rangaswami, M.R. Why sustainability is now the key driver of innovation. Harv. Bus. Rev. 2009, 87, 56-64.

15. Qi, G.Y.; Shen, L.Y.; Zeng, S.X.; Jorge, O.J. The drivers for contractors' green innovation: An industry perspective. J. Clean. Prod. 2010, 18, 1358-1365. [CrossRef] 
16. Matos, S.; Silvestre, B.S. Managing stakeholder relations when developing sustainable business models: The case of the Brazilian energy sector. J. Clean. Prod. 2013, 45, 61-73. [CrossRef]

17. Leal-Rodríguez, L.; Ariza-Montes, A.J.; Morales-Fernández, E.; Albort-Morant, G. Green innovation, indeed a cornerstone in linking market requests and business performance. Evidence from the Spanish automotive components industry. Technol. Forecast. Soc. Chang. 2018, 129, 185-193. [CrossRef]

18. McCain, K.W. Mapping authors in intellectual space: A technical overview. J. Am. Soc. Inf. Sci. 1990, 41, 433-443. [CrossRef]

19. Boyack, R.; Klavans, K.W. Co-citation analysis, bibliographic coupling, and direct citation: Which citation approach represents the research front most accurately? J. Am. Soc. Inf. Sci. Technol. 2010, 61, 2389-2404. [CrossRef]

20. Khalid, R.U.; Seuring, S.; Beske, P.; Land, A.; Yawar, S.A.; Wagner, R. Putting sustainable supply chain management into base of the pyramid research. Supply Chain Manag. Int. J. 2015, 20, 681-696. [CrossRef]

21. Maier, D.; Buzatu, A.; Costache, C.; Maier, A. The creativity role in the innovation management. In Proceedings of the 32nd International Business Information Management Association Conference, IBIMA 2018-Vision 2020: Sustainable Economic Development and Application of Innovation Management from Regional expansion to Global Growth, Seville, Spain, 15-16 November 2018.

22. OECD; Eurostat. The Measurement of Scientific, Technologic1al and Innovation Activities. In Oslo Manual 2018: Guidelines for Collecting, Reporting and Using Data on Innovation, 4th ed.; OECD Publishing: Paris, France; Eurostat: Luxembourg, 2019.

23. Sodano, V. Innovation Trajectories and Sustainability in the Food System. Sustainability 2019, 11, 1271. [CrossRef]

24. Franceschini, J.R.S.; Faria, L.G. Unveiling scientific communities about sustainability and innovation. A bibliometric journey around sustainable terms. J. Clean. Prod. 2016, 127, 72-83. [CrossRef]

25. James, P. The Sustainability Circle: A new tool for product development and design. J. Sustain. Prod. Des. 1997, 2, 52-57.

26. Little, D.A. "The Innovation High Ground Report: How Leading Companies are Using Sustainability-Driven Innovation to Win Tomorrow's Customers.". Available online: https:/www.adlittle.com/sites/default/files/ viewpoints/ADL_Innovation_High_Ground_report_03.pdf (accessed on 15 May 2020).

27. Van Eck, L.; Waltman, N.J. Citation-based clustering of publications using CitNetExplorer and VOSviewer. Scientometrics 2017, 111, 1053-1070. [CrossRef] [PubMed]

28. Zupic, T.C.; Cater, I.Z.; Cater, T. Bibliometric methods in management and organization. Organ. Res. Methods 2015, 18, 429-472. [CrossRef]

29. Nerur, V.; Rasheed, S.P.; Natarajan, A.A. The intellectual structure of the strategic management field: An author co-citation analysis. Strateg. Manag. J. 2008, 29, 319-336. [CrossRef]

30. Corsini, F.; Certomà, C.; Dyer, M.; Frey, M. Participatory energy: Research, imaginaries and practices on people' contribute to energy systems in the smart city. Technol. Forecast. Soc. Chang. 2018, 142, 322-332. [CrossRef]

31. Moher, D.; Liberati, A.; Tetzla, J.; Altman, D.G. Preferred reporting items for systematic reviews and meta-analyses: The PRISMA statement. Ann. Intern. Med. 2009, 151, 1-8. [CrossRef]

32. van Eck, N.J.; Waltman, L. Software survey: VOSviewer, a computer program for bibliometric mapping. Scientometrics 2010, 84, 523-538. [CrossRef]

33. White, H.D.; McCain, K.W. Visualizing a discipline: An author co-citation analysis of information science, 1972-1995. J. Am. Soc. Inf. Sci. 1998, 49, 327-355.

34. Price, D.J.D.S. Networks of scientific papers. Science 1965, 149, 510-515. [CrossRef]

35. Sustainability (Switzerland). Available online: https://www.mdpi.com/journal/sustainability (accessed on 22 February 2020).

36. Journal of Cleaner Production. Available online: https://www.journals.elsevier.com/journal-of-cleanerproduction (accessed on 22 February 2020).

37. Merigó, J.M.; Cancino, C.A.; Coronado, F.; Urbano, D. Academic research in innovation: A country analysis. Scientometrics 2016, 108, 559-593. [CrossRef]

38. Markard, J.; Raven, R.; Truffer, B. Sustainability transitions: An emerging field of research and its prospects. Res. Policy 2012, 41, 955-967. [CrossRef] 
39. Börner, K.; Chen, C.; Boyack, K.W. Visualizing knowledge domains. Annu. Rev. Inf. Sci. Technol. 2003, 37, 179-255. [CrossRef]

40. Callon, M.; Courtial, J.P.; Laville, F. Co-word analysis as a tool for describing the network of interactions between basic and technological research: The case of polymer chemsitry. Scientometrics 1991, 22, 155-205. [CrossRef]

41. Cambrosio, A.; Limoges, C.; Courtial, J.; Laville, F. Historical scientometrics? Mapping over 70 years of biological safety research with coword analysis. Scientometrics 1993, 27, 119-143. [CrossRef]

42. Bhattacharya, S.; Basu, P.K. Mapping a research area at the micro level using co-word analysis. Scientometrics 1998, 43, 359-372. [CrossRef]

43. Waheed, H.; Hassan, S.-U.; Aljohani, N.R.; Wasif, M. A bibliometric perspective of learning analytics research landscape. Behav. Inf. Technol. 2018, 37, 941-957. [CrossRef]

44. Hassan, S.-U.; Visvizi, A.; Waheed, H. The 'who' and the 'what' in international migration research: Data-driven analysis of Scopus-indexed scientific literature. Behav. Inf. Technol. 2019, 38, 924-939. [CrossRef]

45. Maier, D.; Murswieck, R.; Bumbac, R.; Maier, A. Means of Economic Growth through Innovation. In Proceedings of the 2018 BASIQ International Conference, New Trends in Sustainable Business and Consumption, Heidelberg, Germany, 11-13 June 2018; pp. 793-799.

46. Truffer, B.; Coenen, L. Environmental Innovation and Sustainability Transitions in Regional Studies. Reg. Stud. 2012, 46, 1-21. [CrossRef]

47. Bai, X.; Wieczorek, A.J.; Kaneko, S.; Lisson, S.; Contreras, A. Enabling Sustainability Transitions in Asia: The Importance of Vertical and Horizontal Linkages. Technol. Forecast. Soc. Chang. 2009, 76, 255-266. [CrossRef]

48. Ramos-Mejía, M.; Balanzo, A. What It Takes to Lead Sustainability Transitions from the Bottom-up: Strategic Interactions of Grassroots Ecopreneurs. Sustainability 2018, 10, 2294. [CrossRef]

49. Kemp, R.; Van Lente, H. The Dual Challenge of Sustainability Transitions. Environ. Innov. Soc. Transit. 2011, 1, 121-124. [CrossRef]

50. Fagerberg, J. Mobilizing Innovation for Sustainability Transitions: A Comment on Transformative Innovation Policy. Res. Policy 2018, 47, 1568-1576. [CrossRef]

51. Van Geenhuizen, M.; Ye, Q. Responsible Innovators: Open Networks on the Way to Sustainability Transitions. Technol. Forecast. Soc. Chang. 2014, 87, 28-40. [CrossRef]

52. Magnusson, T.; Berggren, C. Competing Innovation Systems and the Need for Redeployment in Sustainability Transitions. Technol. Forecast. Soc. Chang. 2018, 126, 217-230. [CrossRef]

53. Angelidou, M.; Psaltoglou, A. An Empirical Investigation of Social Innovation Initiatives for Sustainable Urban Development. Sustain. Cities Soc. 2017, 33, 113-125. [CrossRef]

54. Coenen, L.; Benneworth, P.; Truffer, B. Toward a Spatial Perspective on Sustainability Transitions. Res. Policy 2012, 41, 968-979. [CrossRef]

55. Baker, S.; Mahmood, A. Social Innovation and the Governance of Sustainable Places. Local Environ. 2015, 20, 321-334. [CrossRef]

56. Edwards-Schachter, M.; Wallace, M.L. 'Shaken, but Not Stirred': Sixty Years of Defining Social Innovation. Technol. Forecast. Soc. Chang. 2017, 119, 64-79. [CrossRef]

57. Oganisjana, K.; Surikova, S. Social Innovation in the Promotion of Sustainable Development of the Contemporary Latvian Society. J. Secur. Sustain. Issues 2015, 5, 249-258. [CrossRef]

58. Desai, R. Teaching Technologists Sustainable Innovation. Int. J. Innov. Sci. 2012, 4, 25-33. [CrossRef]

59. Notten, T. Teaching, Researching and Innovation: An Appetising Programme. Teach. Public Adm. 2016, 34, 70-82. [CrossRef]

60. Barth, M.; Burandt, S. Adding the 'e-' to Learning for Sustainable Development: Challenges and Innovation. Sustainability 2013, 5, 2609-2622. [CrossRef]

61. Colvin, J.; Blackmore, C.; Chimbuya, S.; Collins, K.; Dent, M.; Goss, J.; Ison, R.; Roggero, P.P.; Seddaiu, G. In Search of Systemic Innovation for Sustainable Development: A Design Praxis Emerging from a Decade of Social Learning Inquiry. Res. Policy 2014, 43, 760-771. [CrossRef]

62. De Sousa, L.O.; Richter, B.W.; Raath, S.P. Sustainable Environmental Management Indicators in South African Primary Schools. Sustainability 2017, 9, 854. [CrossRef]

63. Maerean, C.; Albu, E. Measuring Innovation for Sustainable Business Development. Qual. Access Success 2018, 19, 292-297. 
64. Baldassarre, B.; Calabretta, G.; Bocken, N.M.P.; Jaskiewicz, T. Bridging Sustainable Business Model Innovation and User-Driven Innovation: A Process for Sustainable Value Proposition Design. J. Clean. Prod. 2017, 147, 175-186. [CrossRef]

65. Cho, C.; Lee, S. How Firms Can Get Ideas from Users for Sustainable Business Innovation. Sustainability 2015, 7, 16039-16059. [CrossRef]

66. Ali, A.; Frew, A.J. Technology Innovation and Applications in Sustainable Destination Development. Inf. Technol. Tour. 2014, 14, 265-290. [CrossRef]

67. Erzurumlu, S.S.; Erzurumlu, Y.O. Development and Deployment Drivers of Clean Technology Innovations. J. High Technol. Manag. Res. 2013, 24, 100-108. [CrossRef]

68. Shi, Q.; Lai, X. Identifying the Underpin of Green and Low Carbon Technology Innovation Research: A Literature Review from 1994 to 2010. Technol. Forecast. Soc. Chang. 2013, 80, 839-864. [CrossRef]

69. Tigabu, A.D.; Berkhout, F.; van Beukering, P. Technology Innovation Systems and Technology Diffusion: Adoption of Bio-Digestion in an Emerging Innovation System in Rwanda. Technol. Forecast. Soc. Chang. 2015, 90, 318-330. [CrossRef]

70. Moyano-Fuentes, J.; Maqueira-Marín, J.M.; Bruque-Cámara, S. Process Innovation and Environmental Sustainability Engagement: An Application on Technological Firms. J. Clean. Prod. 2018, 171, 844-856. [CrossRef]

71. Severo, E.A.; Dorion, E.C.H.; De Guimarães, J.C.F. Innovation and Environmental Sustainability: Analysis in Brazilian Metal-Mechanic Industry. Int. J. Innov. Sustain. Dev. 2017, 11, 230-248. [CrossRef]

72. Smerecnik, K.R.; Andersen, P.A. The Diffusion of Environmental Sustainability Innovations in North American Hotels and Ski Resorts. J. Sustain. Tour. 2011, 19, 171-196. [CrossRef]

73. Cai, W.; Li, G. The Drivers of Eco-Innovation and Its Impact on Performance: Evidence from China. J. Clean. Prod. 2018, 176, 110-118. [CrossRef]

74. Cecere, G.; Mazzanti, M. Green Jobs and Eco-Innovations in European SMEs. Resour. Energy Econ. 2017, 49, 86-98. [CrossRef]

75. González-Ruiz, J.D.; Botero-Botero, S.; Duque-Grisales, E. Financial Eco-Innovation as a Mechanism for Fostering the Development of Sustainable Infrastructure Systems. Sustainability 2018, 10, 4463. [CrossRef]

76. Urbaniec, M. Towards Sustainable Development through Ecoinnovations: Drivers and Barriers in Poland. Econ. Sociol. 2015, 8, 179-190. [CrossRef]

77. Jo, J.H.; Roh, T.W.; Kim, S.; Youn, Y.C.; Park, M.S.; Han, K.J.; Jang, E.K. Eco-Innovation for Sustainability: Evidence from 49 Countries in Asia and Europe. Sustainability 2015, 7, 16820-16835. [CrossRef]

78. Aguilar-Fernández, M.E.; Otegi-Olaso, J.R. Firm Size and the Business Model for Sustainable Innovation. Sustainability 2018, 10, 4785. [CrossRef]

79. Perić, M.; Vitezić, V.; Mekinc, J. Conceptualising Innovative Business Models for Sustainable Sport Tourism. Int. J. Sustain. Dev. Plan. 2016, 11, 469-482. [CrossRef]

80. Rosca, E.; Arnold, M.; Bendul, J.C. Business Models for Sustainable Innovation-An Empirical Analysis of Frugal Products and Services. J. Clean. Prod. 2017, 162, S133-S145. [CrossRef]

81. Varadarajan, R. Innovating for Sustainability: A Framework for Sustainable Innovations and a Model of Sustainable Innovations Orientation. J. Acad. Mark. Sci. 2017, 45, 14-36. [CrossRef]

82. Evans, S.; Vladimirova, D.; Holgado, M.; Van Fossen, K.; Yang, M.; Silva, E.A.; Barlow, C.Y. Business Model Innovation for Sustainability: Towards a Unified Perspective for Creation of Sustainable Business Models. Bus. Strat. Environ. 2017, 26, 597-608. [CrossRef]

83. Fellnhofer, K. Drivers of Innovation Success in Sustainable Businesses. J. Clean. Prod. 2018, 167, 1534-1545. [CrossRef]

84. Carayannis, E.G.; Sindakis, S.; Walter, C. Business Model Innovation as Lever of Organizational Sustainability. J. Technol. Transf. 2015, 40, 85-104. [CrossRef]

85. Zhao, X.; Chang, T.; Hwang, B.-G.; Deng, X. Critical Factors Influencing Business Model Innovation for Sustainable Buildings. Sustainability 2017, 10, 33. [CrossRef]

86. Inigo, E.A.; Albareda, L.; Ritala, P. Business Model Innovation for Sustainability: Exploring Evolutionary and Radical Approaches through Dynamic Capabilities. Ind. Innov. 2017, 24, 515-542. [CrossRef]

87. França, C.L.; Broman, G.; Robert, K.H.; Basile, G.; Trygg, L. An Approach to Business Model Innovation and Design for Strategic Sustainable Development. J. Clean. Prod. 2017, 140, 155-166. [CrossRef] 
88. Popescu, S.; Dragomir, M.; Pitic, D.; Brad, E. Method for competitive environmental planning. Environ. Eng. Manag. J. 2012, 11, 823-828. [CrossRef]

89. Ahern, J.; Cilliers, S.; Niemelä, J. The Concept of Ecosystem Services in Adaptive Urban Planning and Design: A Framework for Supporting Innovation. Landsc. Urban Plan. 2014, 125, 254-259. [CrossRef]

90. Albort-Morant, G.; Leal-Millán, A.; Cepeda-Carrión, G. The antecedents of green innovation performance: A model of learning and capabilities. J. Bus. Res. 2016, 69, 4912-4917. [CrossRef]

91. Felseghi, R.A.; Carcadea, E.; Raboaca, M.S.; Trufin, C.N.; Filote, C. Hydrogen Fuel Cell Technology for the Sustainable Future of Stationary Applications. Energies 2019, 12, 4593. [CrossRef]

92. Răboacă, M.S.; Badea, G.; Enache, A.; Filote, C.; Răsoi, G.; Rata, M.; Lavric, A.; Felseghi, R.-A. Concentrating Solar Power Technologies. Energies 2019, 12, 1048. [CrossRef]

(C) 2020 by the authors. Licensee MDPI, Basel, Switzerland. This article is an open access article distributed under the terms and conditions of the Creative Commons Attribution (CC BY) license (http://creativecommons.org/licenses/by/4.0/). 